\title{
Influence of temperature and relative humidity on hospital admissions due to pneumonia: a study in the South and Southeast regions of Brazil
}

\section{Influência da temperatura e da umidade relativa nas admissões por pneumonia: um estudo nas regiões sul e sudeste do Brasil}

\author{
Franciele Silva de Barros ${ }^{1}$; Anderson Spohr Nedel ${ }^{2 *}$; João Paulo Assis Gobo ${ }^{3}$; Marina Piacenti- \\ Silva $^{4}$
}

\begin{abstract}
This study aims to evaluate the influence of meteorological factors on hospital admissions for pneumonia in children and elderly in Bauru and Pelotas cities, between 2009 to 2016. The health information was obtained from the Brazilian System Database and the daily average temperature and relative humidity from the meteorological stations of the National Institute of Meteorology and of the UNESP Meteorological Center. Descriptive analyses were performed to verify temporal trends and seasonal variations of meteorological variables and hospitalizations. Spearman correlation and Generalized Additive Model (GAM) Statistical methods were applied too. The results showed that Pelotas, presents the highest frequency of hospitalizations. It's observed an increase in admissions in winter in both cities, except for children, in Bauru/SP, which occurs more frequently in the fall. The correlation was significant for low air temperature and high relative humidity. In addition, the GAM indicated a higher risk of hospitalizations with temperatures below $16^{\circ} \mathrm{C}$ and relative humidity above $40 \%$ (Bauru) and $80 \%$ in Pelotas. The increase in hospitalizations occurs in winter, and caused by the low temperatures and high relative humidity.
\end{abstract}

Key-words: Climate health; Generalized Additive Model; Weather disease

\section{RESUMO}

Este estudo visa avaliar a influência de fatores meteorológicos nas internações por pneumonia em crianças e idosos para as cidades de Bauru/SP e Pelotas/RS no período de 2009 a 2016. Foram realizadas análises descritivas para verificar tendência temporal e variações sazonais dos dados meteorológicos e internações, e aplicou-se métodos estatísticos como correlação de Spearman e Modelo Aditivo Generalizado (MAG). Os resultados obtidos demonstraram que Pelotas apresenta o maior número de internações. Observou-se um aumento nas admissões hospitalares no inverno para as duas cidades, exceto para crianças em Bauru, que ocorre mais no outono. Verificou-se que a correlação foi significativa para temperatura baixa e umidade relativa alta. Além disso, o modelo indicou maior risco de internações com temperaturas abaixo de $16^{\circ} \mathrm{C}$ e umidade relativa acima de $40 \%$ (Bauru) e de $80 \%$ em Pelotas. Portanto, o aumento das internações por pneumonia ocorreu no inverno, e, principalmente, devido à temperatura mínima baixa e umidade relativa alta. ${ }^{1}$

\footnotetext{
${ }^{1}$ Institute of Astronomy, Geophysics and Atmospheric Sciences, University of São Paulo (USP)

${ }^{2}$ Federal University of Southern Border (UFFS), anderson.nedel@uffs.edu.br *Corresponding author

${ }^{3}$ Federal University of Rondônia (UNIR), Department of Geography

${ }^{4}$ Physics Department, São Paulo State University (UNESP), School of Sciences
} 


\section{INTRODUCTION}

Pneumonia is a severe lung infection caused by bacteria, fungi, viruses, or inhalation of toxic substances, and is considered the main cause of death from respiratory infection in the elderly and children (under 5 years old) worldwide. (ANDRADE FILHO et al., 2013; WHO, 2016). Several papers have reported that drastic changes in weather conditions can increase the risk of triggering this disease, the main associated weather conditions being temperature and relative humidity.

Low temperatures can cause direct effects such as hypothermia, and indirect effects such as increased cases of pneumonia, influenza, and other respiratory diseases (KALKSTEIN; GREENE, 1997; SETTE; RIBEIRO, 2011). Furthermore, as the population of children and the elderly is the most influenced by changes in weather and climate (due to greater body thermoregulation problems, and therefore greater sensitivity to environmental factors), an increase in the frequency of respiratory and cardiovascular diseases can be expected (GONCALVES; COELHO, 2010). According to the World Health Organization (WHO), levels below 60\% relative humidity are not adequate for human health and already deserve attention, because they can impact human life. As symptoms, they can cause skin dryness, eye irritation, dryness of the nasal mucous membranes and throat, and rhinitis or flu-related symptoms (ARUNDEL et al., 1986). On the other hand, high relative humidity and high temperature impair heat dissipation and body cooling, because the sweat evaporation process occurs more slowly, contributing to increased heat stress, and consequently the development of respiratory and cardiovascular diseases (ZHANG; YOSHINO, 2010).

It is known that the distribution (and frequency) of diseases can vary according to geographical regions and local climatic conditions. Thus, within the same country or region, different distributions of disease can be found, possibly associated with different meteorological and climatic realities (types of weather and climate), which tend to cause extreme situations and influence humans differently (DA SILVA et al., 2020; QUADRO et al., 2021). Thus, the objective of this paper is to analyze the effect of weather and climate conditions, specifically air temperature and relative humidity, on the occurrence and hospitalization for pneumonia in children and the elderly in two Brazilian regions under different climatic conditions. 


\section{METHODS}

The present study was carried out for the cities of Bauru/SP and Pelotas/RS, located in two regions of the country with extremely different climates. The city of Bauru is located in the central western part of the state of São Paulo, with coordinates $22^{\circ} 18^{\prime} 54^{\prime \prime}$ S e $49^{\circ} 03^{\prime} 39^{\prime \prime} \mathrm{O}$, at 630 meters above sea level. The city has a population of 343,937 inhabitants, according to the Brazilian Institute of Geography and Statistics (IBGE, 2010). Bauru presents summer and winter with well-defined seasons, with less frequent rains in winter. The climate of Bauru is sub-humid, mesothermal, with little humidity in winter according to the Thornthwaite classification, minimum temperatures of $13^{\circ} \mathrm{C}$ (winter) and maximum of $28.5^{\circ} \mathrm{C}$ (summer) (FIGUEIREDO; PAZ, 2010). The systems acting in Bauru are: the South Atlantic Convergence Zone, frontal systems and pre-frontal instability lines responsible for precipitation (CAVALCANTI; FERREIRA; KOUSKY, 1982; MINUZZI et al., 2007).

The city of Pelotas/RS is located in the southern region of the state of Rio Grande do Sul (RS), a geographical position of $31^{\circ} 46^{\prime} 19^{\prime \prime} \mathrm{S}$ e $52^{\circ} 20^{\prime} 34^{\prime \prime} \mathrm{O}$, and altitude of 7 meters with a population of 328,275 inhabitants (IBGE, 2010). According to Köppen's climate classification it has a Cfa climate - humid subtropical - with well distributed rainfall throughout the year and average temperatures around $17.5^{\circ} \mathrm{C}$, ranging from minima of $3.0^{\circ} \mathrm{C}$ (winter) to maxima near $40^{\circ} \mathrm{C}$ (summer) (ALVARES et al., 2013). Another characteristic of this city is that for being located near the Atlantic Ocean (approximately $60 \mathrm{~km}$ ), it suffers great maritime influence, which results in high values of air humidity, and this determines that the summer and winter seasons are characterized as very humid (Figure 1). The region is affected by frontal systems - which are the main causes of rainfall throughout the year - by instability lines, and also suffers the influence of tropical and polar air masses (hot and cold), which cause extreme temperature values during the summer and winter, causing a high degree of thermal stress. This region has the largest annual thermal variability in the country.

Daily meteorological data of temperature (maximum and minimum) and relative humidity (maximum and minimum) were obtained from automatic weather stations, from the IPMet/UNESP and INMET, for the cities of Bauru (SP) and Pelotas (RS), respectively. Such data were obtained daily at 12, 18 and 00 UTC, for the period 2009 to 2016 (eight years). 
Figure 1 - Localization of the cities of Bauru (SP) and Pelotas (RS)

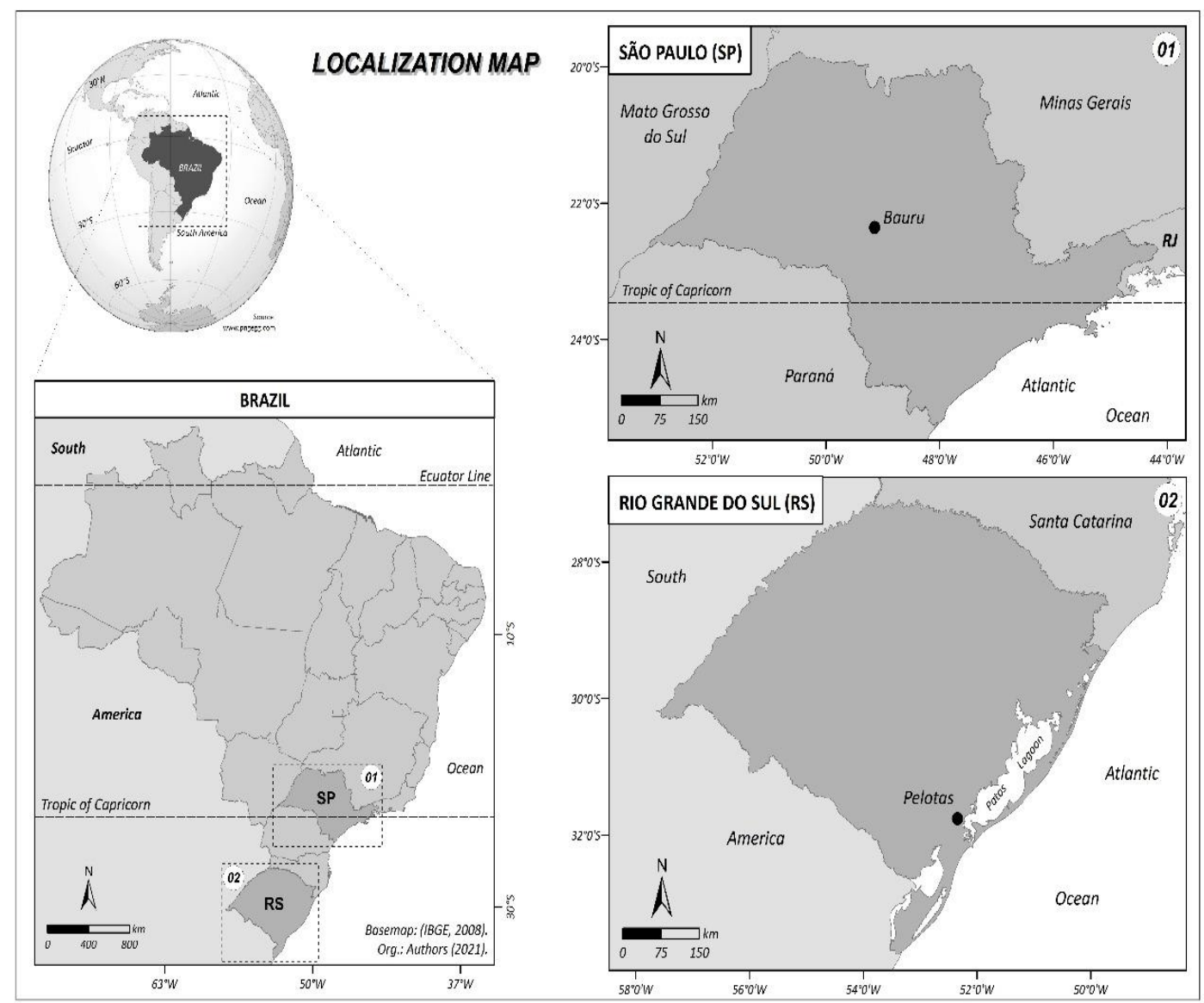

Source: The authors

The methodology consisted of performing descriptive and statistical analysis between the variables using Origin $®$, SPSS $®$ and the free software R. In order to obtain the association between the number of hospitalizations for pneumonia and meteorological variables, Spearman's Correlation Test was used, due to the asymmetric distribution of the data. From the variables that showed the highest correlation with the number of hospital admissions, four models were developed to explain the influence of temperature and relative humidity on the number of hospitalizations. The outcome variables were pneumonia hospitalizations in Bauru and Pelotas by age group ( $<5$ years and $>60$ years), and the explanatory variables were minimum temperature and relative humidity. The daily information on hospital admissions for pneumonia in children $(<5$ years $)$ and elderly (> 60 years), for the cities of Bauru and Pelotas, were obtained through the registers of Authorizations for Hospital Admissions, from the Database of the Brazilian 
Health System (DATASUS), which can be obtained online at www.datasus.gov.br. Among the information in this database are the hospital's registry, the patient's residence municipality, the patient's gender, age, cause of admission, date of entry and exit from the hospital, death, length of stay, days in the Intensive Care Unit (ICU), among others. Therefore, this database can provide enough information to meet the interests of this study. It were selected for the development of this work the variables date of admission, gender, patient's age, municipality of residence and the main diagnosis of hospitalization (cataloged by the tenth revision of the International Code of Diseases - ICD 10).

For this purpose, the generalized additive model (GAM) was used, with a zero-inflated distribution for cases between 0 and 5 years, and a negative binomial distribution for cases over 60 years, in both cities. The adjustments for time trends and seasonality were made by inserting into the models the Cubic Spline function, which smooths the time series (TADANO; UGAYA; FRANCO, 2009). Smoothing curves of this type allow the seasonal pattern to be defined by the data itself, without the need to previously define the shape of this relationship, or the inclusion of other variables that adjust these trends (CONCEIÇÃO; SALDIVA; SINGER, 2001).

\section{RESULTS}

Figure 2 shows the daily values of the meteorological variables during the eight years analyzed. In both cities, there is an evident seasonality of air temperature, with maximum values in summer and minimum values in winter. However, a greater temperature range is observed in Pelotas, when compared to Bauru, as well as extremely low minimum temperatures, close to (and below) zero degrees, and maximum temperatures close to (and above) $35^{\circ} \mathrm{C}$, which, associated with high air humidity throughout the year, cause severe winters and summers, which characterize it as a very humid city and uncomfortable for human health. Bauru, in contrast, is characterized by low relative humidity values during the year (as well as high humidity amplitude) and higher temperatures (in the annual average) than Pelotas.

Figure 2 - Daily time series of meteorological variables for the cities of Bauru and Pelotas from 2009 to 2016. 

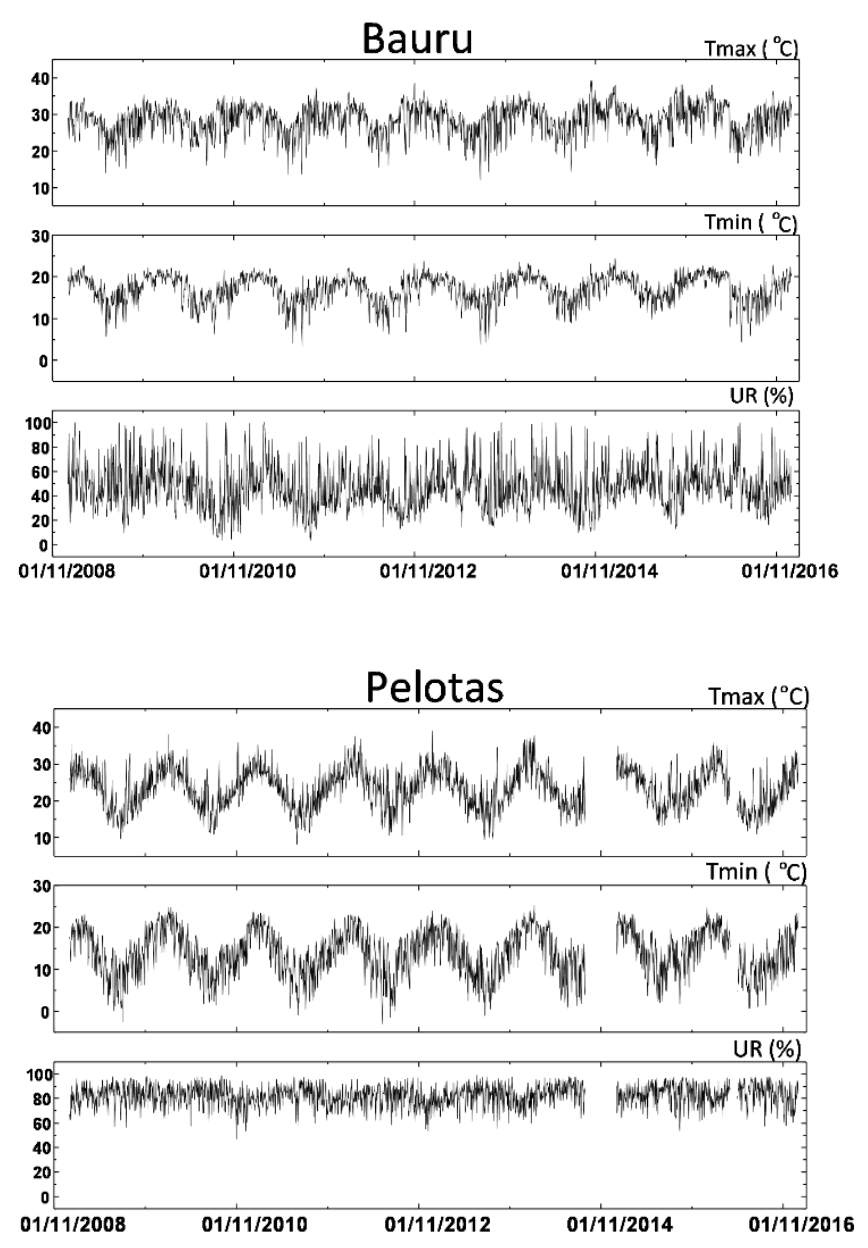

Source: The authors

This analysis can be better detailed when analyzing the average values of meteorological variables, per season (Table I). It can be observed that, regardless of the season, average temperatures are higher in Bauru and average relative humidity values are lower. This can be explained by the latitude and continentality climatic factors between the two cities, since the city of Pelotas is located more southward than Bauru (31 46' 19" S) close to Rio Grande do Sul east coast and Bauru is located farther from the ocean, in the more central region of São Paulo state, with great continentality.

Table 1 - Average observed values of meteorological variables by season, for Bauru/SP and Pelotas/RS.

\begin{tabular}{ccccccc}
\hline & \multicolumn{3}{c}{ Bauru } & \multicolumn{3}{c}{ Pelotas } \\
\hline & T max & T min & UR & T max & T min & UR \\
\hline Summer & 30,6 & 19,9 & 52,1 & 28,5 & 19,3 & 80,6 \\
Autumn & 26,8 & 15,9 & 50,4 & 22,2 & 12,1 & 84,2
\end{tabular}




\begin{tabular}{ccccccc} 
Winter & 26,9 & 14,4 & 39,3 & 18,8 & 9,5 & 84,8 \\
Spring & 30,0 & 17,9 & 45,7 & 23,9 & 14,8 & 79,7 \\
\hline
\end{tabular}

Between the years 2009 and 2016, respectively, 2867 and 3788 cases of hospitalizations for pneumonia were recorded in the cities of Bauru and Pelotas in the elderly (over 60 years old), and 734 and 1698 cases in children (under 5 years old). Figure 3 illustrates the temporal distribution of hospital admissions for pneumonia in children and the elderly for the two cities (Figure 3a), as well as the number of events according to age group and season (Figure $3 b$ ).

Figure 3 - Distribution of pneumonia episodes in children and elderly for Bauru and Pelotas, in the period from 2009 to 2016: a) time series; b) number of hospitalizations per season.

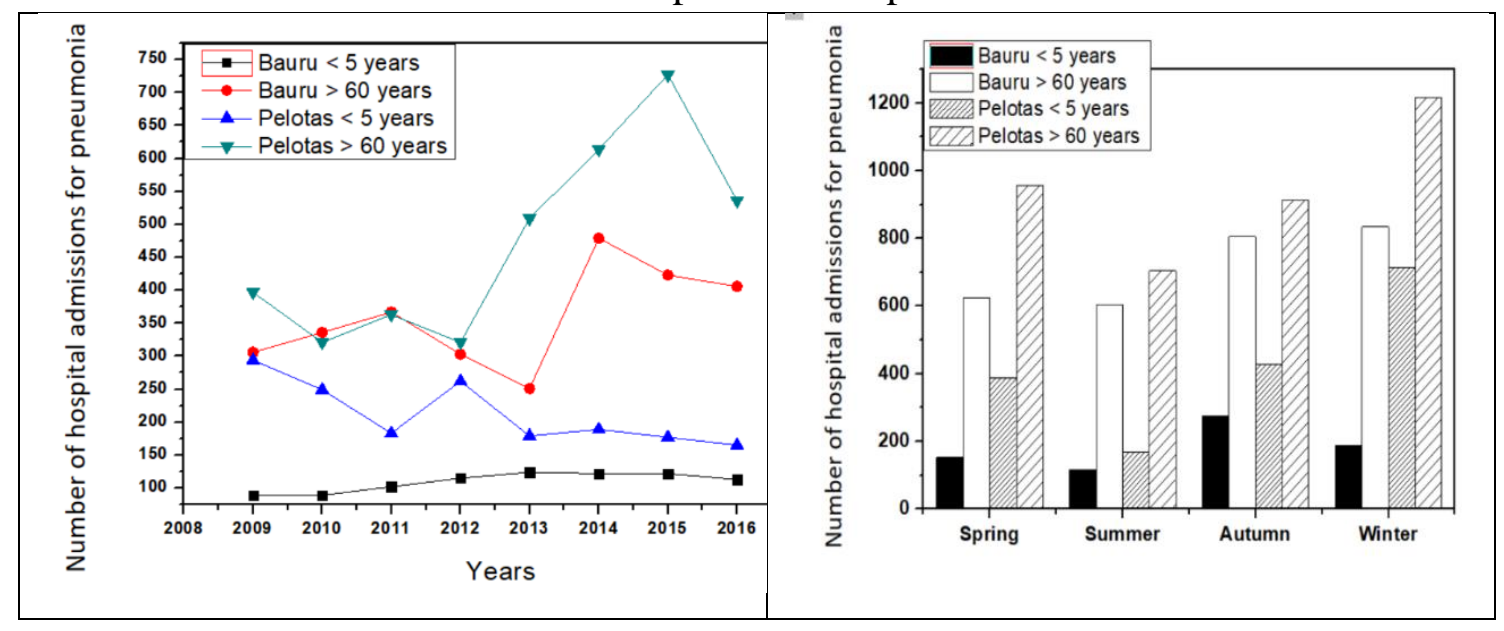

Figure 3 shows that the elderly above 60 years old represent the age group with the highest frequency of hospitalizations for pneumonia in both cities. In addition to the peculiar characteristics of each group studied, which will be discussed later, one of the factors that may justify the lower number of cases of pneumonia in children under 5 years of age is the introduction of the pneumococcal vaccine in 2010 in the Brazilian Health System. Studies show that vaccination may have contributed to the decrease in the number of pneumonia cases in children mainly in the city of Pelotas (Figure 3a) (KUPEK; VIEIRA, 2016). As seen in Figure 3b, it is evident for all groups that the hottest months presented the lowest records of pneumonia (summer and fall), and that the city of Pelotas presented a higher incidence of this disease when compared with Bauru, regardless of the season and of the age range (less than five or more than 60 years of age). It is also worth mentioning the high difference in the occurrence of the disease in children under five 
years of age between Bauru and Pelotas, with the latter presenting three times the number of hospitalizations observed in Bauru.

The highest hospitalization frequencies in patients older than 60 years occurred in winter and fall in the city of Bauru, and in the southernmost city of Brazil (Pelotas), such diseases predominated in winter and spring. This fact may be associated with the decrease in temperature and increase in relative humidity in both cities, as observed in Table 1. The exception is that the spring season, in the state of RS, still presents (on average) low temperatures in the morning, which does not occur in Bauru (whose spring is milder). The population over 60 is considered at risk for several factors, among which: having a weakened immune system due to the natural aging of the body; natural aging of the respiratory epithelium cilia, increasing the chances of contracting infectious diseases. Thus, the drop in temperature weakens the immune system, facilitating the entry of external elements (FELDMAN, 1999; FILHO et al., 2004; LOEB, 2004; SHARMA; GOODWIN, 2006; SOUZA; SANTOS; APARECIDA, 2014). Moreover, with the improvement in the life quality and the advance of public health in Brazil, the elderly population has been growing, however, due to the natural aging of the organism this group is more sensitive, being affected in a more aggressive way by infectious agents (WOLFF, 2016).

The group of patients under 5 years old is also very affected by pneumonia. It is observed that the highest number of cases occur in the fall in Bauru and in the winter in Pelotas, seasons that combine, respectively in each of the cities, the conditions of low temperatures and high air humidity. It is noteworthy that during the fall (late) the first polar masses begin to enter the continent (causing large drops in temperature) and great impact on humans (since the human body is still "used to/adapted" to the high temperatures of the summer season). This age group is (as well as those over 60), very susceptible to the development of pneumonia, possibly due to its immature immune system, which facilitates the evolution of infectious agents, and the reduced dimensions of the airways, allowing a clinical condition more vulnerable to bacteria (MACEDO et al., 2007; NATALI et al., 2011). In addition, because they are at the beginning of school age, they can be infected due to small outbreaks in schools (CORREIA et al., 2005).

Table II presents the results of Spearman's Correlation test, in order to evaluate a possible association between the number of hospitalizations for pneumonia and the meteorological variables evaluated in this study. The correlation between the variables was performed using a lag of four days, since the responses of the human body (in this 
case, pneumonia) to weather conditions vary between regions and there may be a delay of a few days between the meteorological event (variation in temperature and air humidity) and the development of the disease.

Table 2 - Results of Spearman's Correlation test.

\begin{tabular}{c|cccc|cccc}
\hline \multirow{2}{*}{} & \multicolumn{5}{|c|}{ Bauru } & \multicolumn{4}{c}{ Pelotas } \\
\cline { 2 - 8 } & $<5$ years & $>60$ years & Tmax & Tmin & $<5$ years & $>60$ years & Tmax & Tmin \\
\hline$>60$ years & $0,044^{*}$ & - & & & $0,082^{* *}$ & - & \\
Tmax & $-0,091^{* *}$ & $-0,090^{* *}$ & - & & $-0,260^{* *}$ & $-0,145^{* *}$ & - & \\
Tmin & $-0,078^{* *}$ & $-0,087^{* *}$ & $0,632^{* *}$ & - & $-0,276^{* *}$ & $-0,121^{* *}$ & $0,772 * *$ & - \\
UR & $0,038^{*}$ & 0,018 & $-0,482^{* *}$ & $0,187^{* *}$ & $0,054^{* *}$ & $0,063^{* *}$ & $-0,246^{* *}$ & $0,057^{* *}$ \\
\hline
\end{tabular}

The results of Spearman's Correlation test show that the frequency of hospitalizations for pneumonia, for the age groups studied, correlates with air temperature, as well as with the increase in relative humidity (ANDRADE et al., 2015). This result is observed in both cities. Although the correlation indices were low, the correlations were significant $(\mathrm{p}<0.05)$ with a $95 \%$ confidence interval. Based on this result, considering that the number of hospitalizations can increase with the increase in relative humidity, or with the decrease in air temperature, four models were developed using as explanatory variables minimum temperature and relative humidity, and as response variable: a) risk of hospitalizations in Bauru from 0 to 5 years old; b) risk of hospitalizations in Bauru of 60 years old or older; c) risk of hospitalizations in Pelotas from 0 to 5 years old; d) risk of hospitalizations in Pelotas of 60 years old or older. Figure 4 presents the results of the four models developed, in the form of estimated smoothing curves for the risk of pneumonia hospitalizations as a function of the explanatory variables, by city and age group.

The fitted curves of all models suggest that the risk of hospitalizations increases considerably in the presence of low temperatures and high air humidity. Figures $4 \mathrm{a}, 4 \mathrm{c}$, $4 \mathrm{e}$, and $4 \mathrm{~g}$ show the fitted smoothing curves for risk of hospital admissions as a function of minimum temperature. In general, for temperatures below $16^{\circ} \mathrm{C}$, the number of hospitalizations increases as the temperature decreases, except in Bauru for the age group 60 years and older, where the decrease in temperature does not seem to affect the number of hospitalizations. 
The impact of relative humidity shown in Figures $4 \mathrm{~b}, 4 \mathrm{~d}, 4 \mathrm{f}$ and $4 \mathrm{~h}$, indicates that the risk of hospitalizations tends to increase when this variable is above $40 \%$ in Bauru and above $80 \%$ in Pelotas.

Figure 4 - Effects of minimum temperature and relative humidity by age group on the risk of hospitalizations for pneumonia in Bauru and Pelotas.

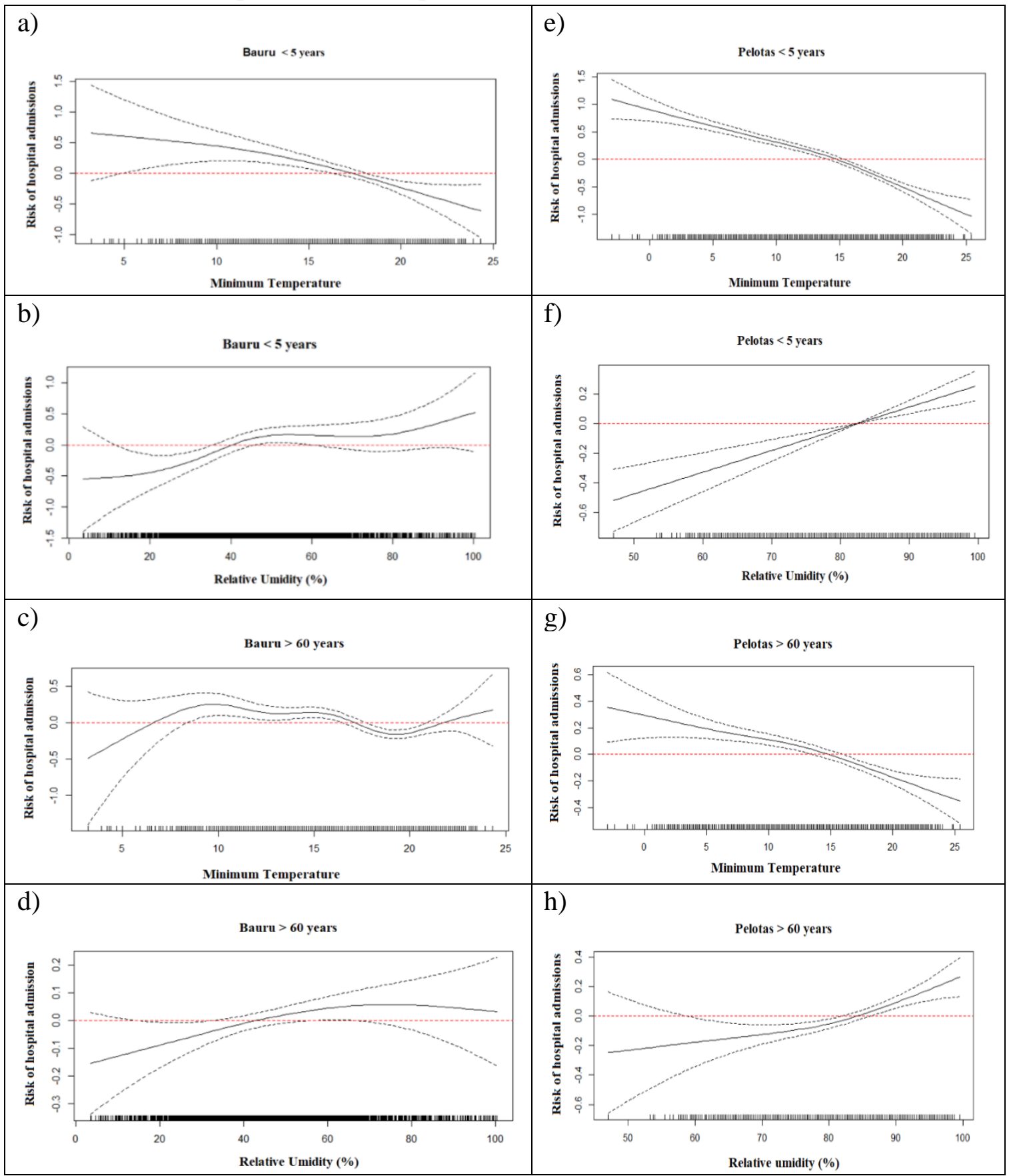

Source: the authors

\section{DISCUSSION}


This epidemiological study carried out for the cities of Bauru/SP and Pelotas/RS, investigates the association of temperature and humidity in hospitalizations for pneumonia in children and the elderly. The main results of this study show that the number of hospitalizations for pneumonia in both children and the elderly increases when the combination of low temperature and high humidity conditions are associated. These results agree with other studies, which observe higher frequencies of hospital admissions in children on colder days (BAKONYI et al., 2004; GONCALVES; COELHO, 2010; NEDEL et al., 2009; PONTES et al., 2016). This climatic pattern observed for the increase in hospitalizations for pneumonia justifies the epidemiological profile according to the seasons in both cities studied in this study. The large number of hospitalizations in the fall and winter in Bauru is justified by the low temperatures in the fall, similar to those in winter, but with higher relative humidity. In Pelotas, low temperatures and high relative humidity are present practically the entire year, but more pronouncedly during winter, classifying it as cold and humid. These results agree with the studies of Pontes et al. (2016), for the city of Ponta Grossa/PR, where winter is indicated as the season with the highest frequency of hospital admissions, followed by the transition months such as fall and spring (LIEBERMAN; LIEBERMAN; FRIGER, 1999; TOYOSHIMA; ITO; GOUVEIA, 2005). Autumn, considered a period of transition between summer and winter, already begins to bring colder and more humid air, due to the greater frequency of the passage of cold air masses from the south. They promote more intense winds and sudden changes in temperature, impacting human health and making the body more susceptible to microorganisms. (EMÍDIO; LIMA, 2017; NATALI et al., 2011). The increased occurrence of cold fronts and the consequent drop in temperature can also help the proliferation of infectious agents, since the cold air paralyzes the cilia that cover the walls of the respiratory tract (WEST, 2013). In addition, the lack of ventilation, due to rooms being closed up because of the cold, can increase the spread of allergens among people.

It is important to emphasize that the results observed from the models obtained consider as explanatory variables only the minimum temperature and relative humidity, which show better correlation. However, other factors can also be considered important covariates. In the literature, it has been found that pneumonia hospitalizations in the child population of São José dos Campos/SP (NASCIMENTO et al., 2006), demonstrates association to the effects of air pollution, as well as on morbidities by respiratory diseases in Curitiba/PR (BAKONYI et al., 2004), indicating that the health impacts are not 
restricted to large cities. The elderly are also affected by air pollution as shown in the study by Martins et al. (2002), which associated pollutants such as ozone and sulfur dioxide with the number of cases of pneumonia in the São Paulo Metropolitan Region (RMSP). Another important factor is the presence of chronic conditions, especially in the elderly, as noted by studies conducted in Finland (KOIVULA; STEN; MAKELA, 1994) and United States (MANNINO; DAVIS; KIRI, 2009), that Chronic Obstructive Pulmonary Disease, cardiovascular disease, and diabetes were correlated with increased risk of developing pneumonia. In addition, social factors such as economic conditions, education levels, and health care network, may contribute to the advancement of the disease (GOYA; FERRARI, 2005).

Research on pneumococcal vaccine has shown that the impact of vaccination produces a significant reduction in pneumonia hospitalizations in children under one year of age in Santa Catarina (VIEIRA; KUPEK, 2018) and in children under two years of age in Recife/PE, Belo Horizonte/MG and Curitiba/PR (AFONSO et al., 2013). However, there is a need for further studies to analyze the efficacy of the vaccine in the elderly in Brazil. On the other hand, the studies on Influenza vaccine showed evidence of reduction of hospitalizations in the elderly by preventing pneumonia due to viral causes (DAUFENBACH et al., 2014). In this context, preventive measures such as increased vaccination coverage and effective diagnostics to apply the best treatment should be taken to avoid pneumonia, which in more severe cases can lead to death. However, the present study verified the association between the variables temperature and relative humidity and hospital admissions for pneumonia in children and elderly in Bauru/SP and Pelotas/RS. In general, the results found can support management strategies and be a useful tool for decision making by public managers and health professionals. The disclosure of information about periods favorable to a higher frequency of the disease can be used as an alert and contribute to the reduction of hospital admissions and consequently reduce the costs of the public health sector.

\section{ACKNOWLEDGEMENT}

We thank the funding agency FAPESP (Process 2015/22864-2) for supporting this research.

\section{REFERENCES}

AFONSO, E. T. et al. Effect of 10-valent pneumococcal vaccine on pneumonia among children, Brazil. Emerging Infectious Diseases, v. 19, n. 4, p. 589-597, 2013. 
ALVARES, C. A. et al. Köppen's climate classification map for Brazil.

Meteorologische Zeitschrift, v. 22, n. 6, p. 711-728, 1 dez. 2013.

ANDRADE, D. DE O. et al. Sazonalidade Climática E Hospitalizações Em Crianças Menores De Cinco Anos Com Doença Respiratória, Goiânia/Go. Hygeia, v. 11, n. 20, p. 99-105, 2015.

ANDRADE FILHO, V. S. DE et al. Aerossois de queimadas e doencas respiratorias em criancas, Manaus, Brasil. Revista de Saúde Pública, v. 47, n. 2, p. 239-247, 2013.

ARUNDEL, A. V. et al. Indirect health effects of relative humidity in indoor environments. Environ Health Perspect, v. 65, n. 3, p. 351-361, 1986.

BAKONYI, S. M. C. et al. Poluição atmosférica e doenças respiratórias em crianças na cidade de Curitiba, PR. Revista de Saude Publica, v. 38, n. 5, p. 695-700, 2004.

CAVALCANTI, I. F. A.; FERREIRA, N. J.; KOUSKY, V. E. Análise de um caso de atividade convectiva associada a linhas de instabilidade na Região Sul e Sudeste do Brasil. INPE-2574-PRE/222

CONCEIÇÃO, G. M. DE S.; SALDIVA, P. H. N.; SINGER, J. DA M. Modelos MLG e MAG para análise da associação entre poluição atmosférica e marcadores de morbimortalidade: uma introdução baseada em dados da cidade de São Paulo. Revista Brasileira de Epidemiologia, v. 4, n. 3, p. 206-219, 2001.

CORREIA, P. et al. Infecção respiratória a Chlamydia pneumoniae. Acta Medica Portuguesa, 2005.

DA SILVA, I. et al. Risk assessment of temperature and air pollutants on hospitalizations for mental and behavioral disorders in Curitiba, Brazil. Environmental Health: A Global Access Science Source, v. 19, n. 1, 2020.

DAUFENBACH, L. Z. et al. Impacto da vacinação contra a influenza na morbidade hospitalar por causas relacionadas à influenza em idosos no Brasil. Epidemiologia e Serviços de Saúde, v. 23, n. 1, p. 9-20, 2014.

EMÍDIO, Z. P. O.; LIMA, I. T. Estações do ano.

FELDMAN, C. Pneumonia in the Elderly. Clinics in Chest Medicine, v. 20, n. 3, p. 563-573, 1999.

FIGUEIREDO, J. C.; PAZ, R. DA S. Nova classificação climática e o aspecto climatológico da cidade. XVI Congresso Brasileiro de Meteorologia. Anais Revista Brasileira de Meteorologia, 2010

FILHO, A. I. DE L. et al. Causas de internações hospitalares entre idosos brasileiros no âmbito do Sistema Único de Saúde *. Epidemiologia e Serviços de Saúde, v. 13, n. 4, p. 229-238, 2004.

GONCALVES, F. L. T.; COELHO, M. DE S. Z. S. Variação Da Morbidade De Doenças Respiratórias Em Função Da Variação Da Temperatura Entre Os Meses De Abril E Maio Em São Paulo. Ciência e Natura, v. 32, n. 1, p. 103-118, 2010. 
GOYA, A.; FERRARI, G. Fatores de risco para morbimortalidade por pneumonia em crianças. Cep, v. 23, n. 2, p. 99-105, 2005.

IBGE. 2021. Departamento de Censos. Disponivel em www.ibge.gov.br. Acessado em 05.09.2021.

KALKSTEIN, L. S.; GREENE, J. S. An evaluation of climate/mortality relationships in large U.S. cities and the possible impacts of a climate change. Environmental Health Perspectives, v. 105, n. 1, p. 84-93, 1997.

KOIVULA, I.; STEN, M.; MAKELA, P. H. Risk factors for pneumonia in the elderly. The American Journal of Medicine, v. 96, n. 4, p. 313-320, 1994.

KUPEK, E.; VIEIRA, I. L. V. O impacto da vacina pneumocócica PCV10 na redução da mortalidade por pneumonia em crianças menores de um ano em Santa Catarina, Brasil. Cadernos de Saude Publica, v. 32, n. 3, p. 1-11, 2016.

LIEBERMAN, D.; LIEBERMAN, D.; FRIGER, M. D. Seasonal Variation in Hospital Admissions for Community-acquired Pneumonia: A 5-Year Study. Journal of Infection, v. 39, p. 134-140, 1999.

LOEB, M. Pneumonia in the elderly. Current Opinion in Infectious Diseases, v. 17, n. 2, p. 127-130, 2004.

MACEDO, S. E. C. et al. Fatores de risco para internação por doença respiratória aguda em crianças até um ano de idade. Revista de Saude Publica, v. 41, n. 3, p. 351-358, 2007.

MANNINO, D. M.; DAVIS, K. J.; KIRI, V. A. Chronic obstructive pulmonary disease and hospitalizations for pneumonia in a US cohort. Respiratory Medicine, v. 103, n. 2, p. 224-229, 2009.

MARTINS, L. C. et al. Air pollution and emergency room visits due to pneumonia and influenza in São Paulo, Brazil. Revista de Saude Publica, v. 36, n. 1, p. 88-94, 2002.

MINUZZI, R. B. et al. CLIMATOLOGIA DO COMPORTAMENTO DO PERÍODO CHUVOSO DA REGIÃO SUDESTE DO BRASIL. Revista Brasileira de, v. 22, n. 3, p. 338-344, 2007.

NASCIMENTO, L. F. C. et al. Efeitos da poluição atmosférica na saúde infantil em São José dos Campos, SP Effects of air pollution on children' $s$ health in a city in Southeastern Brazil. Revista Saúde Pública, v. 40, n. 1, p. 77-82, 2006.

NATALI, R. M. DE T. et al. Perfil de internações hospitalares por doenças respiratórias em crianças e adolescentes da cidade de são paulo, 2000-2004. Revista Paulista de Pediatria, v. 29, n. 4, p. 584-590, 2011.

NEDEL, A. S. et al. Evaluation of thermal simulation of households in the metropolitan region of São Paulo, Brazil. Ecotoxicology, v. 18, n. 8, p. 1143-1149, 2009.

PONTES, C. C. et al. EFEITOS DO CLIMA NA SAÚDE: ANÁLISE DAS INTERNAÇÕE.S DE CRIANÇAS MENORES DE CINCO ANOS POR 
PNEUMONIA NO MUNICÍPIO DE PONTA GROSSA - PR. Revista Brasileira de Climatologia, p. 38-52, 2016.

QUADRO, M. F. L. et al. Meteorological conditions and thermal comfort during the athletic events of the olympic games in Rio de Janeiro in 2016. Anais da academia brasileira de ciencias, v. 93, n. 1, 2021.

SETTE, D. M.; RIBEIRO, H. Interações entre o clima, o tempo e a saúde humana.

Revista de Saúde Meio Ambiente e Sociedade, v. 6, n. 2, p. 37-51, 2011.

SHARMA, G.; GOODWIN, J. Effect of aging on respiratory system physiology and immunology. Clinical interventions in aging, v. 1, n. 3, p. 253-260, 2006.

SOUZA, D.; SANTOS, S.; APARECIDA, D. Hospitalizações por infecção respiratória associada a fatores ambientais. Revista Brasileira em Promoção da Saúde, v. 27, n. 3 , p. 312-318, 2014.

TADANO, Y. DE S.; UGAYA, C. M. L.; FRANCO, A. T. Método de regressão de Poisson: Metodologia para avaliação do impacto da poluição atmosférica na saúde populacional. Ambiente e Sociedade, v. 12, n. 2, jul. 2009.

TOYOSHIMA, M. T. K.; ITO, G. M.; GOUVEIA, N. Morbidade por doenças respiratórias em pacientes hospitalizados em São Paulo/SP. Revista da Associacao Medica Brasileira, v. 51, n. 4, p. 209-213, 2005.

VIEIRA, I. L. V.; KUPEK, E. Impacto da vacina pneumocócica na redução das internações hospitalares por pneumonia em crianças menores de 5 anos, em Santa Catarina, 2006 a 2014. Epidemiologia e servicos de saude : revista do Sistema Unico de Saude do Brasil, v. 27, n. 4, p. e2017378, 2018.

VIRGI, H. A preliminary study of summertime tropospheric circulation patterns over South America estimated from cloud wins. Weather Magazine, p. 549-610, 1981.

WEST, J. B. Fisiologia respiratória. 9. ed. Artmed, 2013.

WHO. Pneumonia. Disponível em https://www.who.int/health-topics/pneumonia. Acessado em 05.07.2021.

WOLFF, P. Pneumonia em idosos. Revista Uniplac, v.4, n.1, 2016.

ZHANG, H.; YOSHINO, H. Analysis of indoor humidity environment in Chinese residential buildings. Building and Environment, v. 45, n. 10, p. 2132-2140, 2010. 